\title{
Penerapan model pembelajaran treffinger untuk meningkatkan kemampuan berpikir kreatif matematis siswa
}

\author{
Rusdian Rifa'i, Asep Sujana, Ira Romdonah \\ Program Studi Pendidikan Matematika Universitas Mathla'ul Anwar \\ Jalan Raya Labuan KM. 23, Cikaliung, Saketi, Pandeglang, Banten \\ rusdianrifai@gmail.com
}

Received: 17 Maret 2019 ; Accepted: 27 Mei 2019 ; Published: 20 Juni 2020

\begin{abstract}
Abstrak
Penelitian ini bertujuan untuk mengetahui peningkatan kemampuan berpikir kreatif matematis siswa kelas XI Madrasah Aliyah Mathla'ul Anwar Pusat Menes melalui model pembelajaran treffinger. Penelitian ini menggunakan metode kuasi eksperimen yang berdesain the nonequivalent pretest-posttest control group design, sedangkan teknik penelitian yang digunakan adalah purposive sampling dimana dalam menentukan sampel berdasarkan pertimbangan tertentu. Populasi dalam penelitian ini adalah seluruh siswa-siswi kelas XI Madrasah Aliyah Mathla'ul Anwar Pusat Menes, sedangkan sampel yang digunakan adalah siswa kelas XI IPA 1 dan XI IPA 2 Madrasah Aliyah Mathla'ul Anwar Pusat Menes. Prosedur pengumpulan data dalam penelitian ini menggunakan metode observasi dan tes. Instrumen yang digunakan dalam penelitian ini adalah tes kemampuan berpikir kreatif matematis siswa berbentuk tes uraian. Data yang diperoleh dalam penelitian ini berupa data kuantitatif. Pengolahan data kuantitatif dilakukan melalui uji normalitas, uji homogenitas, uji perbedaan rata-rata. Statitik yang digunakan dalam mengolah data adalah statistik parametrik dengan uji-t. Berdasarkan hasil pengolahan data dan pengujian hipotesis diperoleh kesimpulan bahwa kemampuan berpikir kreatif matematis siswa kelas XI Madrasah Aliyah Mathla'ul Anwar Pusat Menes yang memperoleh model pembelajaran treffinger lebih baik dari pada siswa yang memperoleh pembelajaran konvensional.
\end{abstract}

Kata kunci: Model treffinger, berpikir kreatif matematis

\begin{abstract}
This study aims to determine the improvement of mathematical creative thinking skills of class XI students of Aliyah Mathla'ul Anwar Madrasah Menes Center through the treffinger learning model. This study uses a quasi-experimental method that is nonequivalent pretest-posttest control group design, while the research technique used is purposive sampling where in determining the sample based on certain considerations. The population in this study were all students of class XI of the Aliyah Mathla'ul Anwar Madrasah Menes Center, while the sample used was students of class XI IPA 1 and XI IPA 2 Aliyah Mathla'ul Anwar Madrasah Menes Center. The procedure for collecting data in this study uses the observation and test methods. The instrument used in this study was a test of students' mathematical creative thinking skills in the form of a description test. The data obtained in this study are quantitative data. Quantitative data processing is done through normality test, homogeneity test, average difference test. The statistics used in processing data are parametric statistics with $t$-test. Based on the results of data processing and hypothesis testing, it was concluded that mathematical creative thinking skills of class XI students of Aliyah Madrasah Mathla'ul Anwar Menes Center who obtained the Treffinger learning model were better than students who obtained conventional learning.
\end{abstract}

Keywords: Treffinger model, mathematical creative thinking 


\section{PENDAhuluan}

Pendidikan merupakan salah satu hal yang sangat penting untuk menciptakan sumber daya manusia yang berkualitas. Sebagaimana tercantum dalam Undang-Undang Republik Indonesia Nomor 20 Tahun 2003 tentang Sistem Pendidikan Nasional pasal yang menyatakan bahwa pendidikan nasional berfungsi mengembangkan kemampuan dan membentuk watak serta peradaban bangsa yang bermartabat dalam rangka mencerdaskan kehidupan bangsa, bertujuan untuk berkembangnya potensi peserta didik agar menjadi manusia yang beriman dan bertakwa kepada Tuhan Yang Maha Esa, berakhlak mulia, sehat, berilmu, cakap, kreatif, mandiri dan menjadi warga negara yang demokratis serta bertanggung jawab.

Matematika memiliki peranan yang sangat penting karena matematika merupakan salah satu ilmu yang mendasari perkembangan ilmu pengetahuan dan teknologi. Berdasarkan hal tersebut untuk mencapai tujuan dari pembelajaran, salah satu aspek yang harus dikuasai siswa adalah memiliki kemampuan berpikir kreatif matematis. Puccio dan Mudock (Moma, 2015: 28) bahwa dalam berpikir kreatif memuat aspek keterampilan kognitif dan metakognitif antara lain mengidentifikai masalah, menyusun pertanyaan, mengidentifikasi data yang relevan dan tidak relevan, produktif, menghasilkan banyak ide, ide yang berbeda dan produk atau ide yang baru dan memuat disposisi yaitu bersikap terbuka, berani mengambil posisi, bertindak cepat, bersikap atau berpandangan bahwa sesuatu adalah bagian dari keseluruhan yang kompleks, memanfaatkan cara berpikir orang lain yang kritis, dan sikap sensitif terhadap perasaan orang lain. Diperlukan strategi pembelajaran untuk mengatasinya, yang dapat mendorong siswa untuk lebih aktif (Rahayu, dkk:2019).
Guilford (Munandar, 2012: 8) mengungkapkan bahwa pengembangan kreativitas ditelantarkan dalam pendidikan formal, padahal amat bermakna bagi pengembangan potensi anak bagi kemajuan ilmu pengetahuan dan seni budaya. Berdasarkan observasi di Madrasah Aliyah Mathla'ul Anwar Pusat Menes, ternyata siswa yang memiliki kemampuan berpikir kreatif matematis masih rendah. Hal ini dapat dilihat dari belum mampunya siswa memberikan jawaban yang berbeda. Rendahnya kemampuan berpikir kreatif ini dapat dilihat dari hasil tes siswa yang belum mencapai KKM yaitu 69. Nilai Kriteria Ketuntasan Maksimal (KKM) adalah 79. Ratarata nilai tersebut jelas kurang memuaskan karena nilai rata-rata yang diperoleh idealnya melebihi dari standar KKM. Pembelajaran yang menciptakan kondisi siswa merasa nyaman, tertantang untuk mau berpikir, hal ini dapat terwujud salah satunya apabila guru menyiapkan standar proses pembelajaran dengan tepat, baik dan terukur (Sobarningsih, dkk:2019).

Salah satu upaya untuk meningkatkan kemampuan berpikir kreatif matematis siswa adalah dengan menggunakan penerapan model pembelajaran treffinger. Model treffinger terdiri dari tiga langkah yaitu basic tools, Practice with process, dan working with real problems. Tahap basic tools yaitu pengembangan fungsi divergen, tahap practice with process merupakan proses berpikir dan perasaan majemuk, dan tahap working with real problems merupakan keterlibatan penyelesaian masalah secara kreatif. Supaya dapat mengetahui dan mendiskripsikan bagaimana meningkatkan kemampuan berpikir kreatif siswa dalam memecahkan masalah matematika.

Binet (Yusuf 2016: 106) menyatakan bahwa sifat hakikat intelegensi itu ada tiga macam, yaitu: (a) kecerdasan untuk menetapkan dan mempertahankan tujuan tertentu. Semakin cerdas seseorang, akan semakin cakaplah dia

Jurnal Analisa 6 (1) (2020):1-9 
Penerapan model pembelajaran treffinger untuk meningkatkan kemampuan berpikir kreatif matematis siswa

memperintah saja; (b) kemampuan untuk mengadakan penyesuaian dalam rangka mencapai tujuan tersebut; (c) kemampuan untuk melakukan otoritik, kemampuan untuk belajar dari kesalahan yang telah dibuatnya. Salah satu tingkah laku intelegen dibentuk melalui insight, kemampuan untuk menghadapi situasi baru secara efektif. Kemampuan berpikir secara sistematis dapat membentuk pola berpikir yang tertib, teliti dan logis (Sobarningsih, dkk: 2019).

Marzano (Meika \& Sujana, 2015: 2) menyatakan bahwa untuk menjadi kreatif seseorang harus: (1) bekerja di ujung kompetensi bukan ditengahnya, (2) tinjau ulang ide, (3) melakukan sesuatu karena dorongan internal dan bukan eksternal, (4) pola pikir divergen/menyebar, (5) pola pikir lateral/imajinatif. Menurut Munandar (2012: 12) bahwa kreativitas merupakan hal yang bisa dikuasai oleh setiap orang dengan didukung oleh lingkungannya. Aktivitas-aktivitas tertentu dalam lingkungan yang memadai akan menumbuhkan orang-orang yang mampu untuk berpikir kreatif supaya ketika ada permasalahan dalam lingkungannya, seseorang tersebut mampu memecahkannya. Oleh karena itu, guru dapat membantu perbaikan proses pembelajaran berpikir kreatif.

Wallas (Munandar 2012: 39) mengemukakan bahwa tahapan berpikir kreatif ada empat yaitu persiapan (preparation), Inkubasi (Incubation), Iluminasi (Iluminasi) dan verifikasi (verification). Persiapan (preparation) seseorang mempersiapkan diri untuk memecahkan masalah dengan belajar berpikir, mencari jawaban, bertanya kepada orang, dan sebagainya. Inkubasi (Incubation) kegiatan mencari menghimpun data atau informasi tidak dilanjutkan. Tahap inkubasi ialah tahap dimana individu seakan-akan melepaskan diri untuk sementara dari masalah tersebut, dalam arti bahwa ia tidak memikirkan secara sadar, tetapi "menggeramnya" dalam alam pra sadar. Iluminasi (Iluminasi) tahap ini sering disebut sebagai tahap timbulnya insight. Pada tahap ini sudah dapat timbul inspirasi atau gagasan-gagasan baru serta proses-proses psikologi yang mengawali dan mengikuti munculnya inspirasi atau gagasan baru. Verifikasi (Verification) tahap dimana ide atau kreasi baru tersebut harus diuji terhadap realitas. Disini diperlukan pemikiran kritis dan konvergen. Dengan perkataan lain, proses divergensi (pemikiran kreatif) harus diikuti oleh proses konvergensi (pemikiran kritis).

Torrance (Moma 2015: 28) mengungkapkan bahwa indikator kemampuan berpikir kreatif matematis siswa diantaranya seperti pada Tabel 1 berikut.

Tabel 1. Indikator Berpikir Kreatif Matematis

\begin{tabular}{cl}
\hline Aspek & \multicolumn{1}{c}{ Indikator } \\
\hline Kelancaran & Mempunyai banyak \\
(fluency) & ide/gagasan dalam berbagai \\
keluwesan & Mempunyai ide/gagasan yang \\
(flexibility) & beragam \\
Keaslian & Mempunyai ide/gagasan baru \\
(originality) & untuk menyelesaikan \\
& persoalan \\
Elaborasi & Mampu mengembangkan \\
ide/gagasan untuk \\
(elaboration) & menyelesaikan masalah secara \\
& rinci \\
\hline
\end{tabular}

Berdasarkan Tabel 1 dapat disimpulkan bahwa keempat karakteristik berpikir kreatif yakni kelancaran, keluwesan, keaslian dan elaborasi akan memberikan suatu pandangan tentang proses kreatif yang akan membantu individu untuk menciptakan ide-ide kreatif dalam menyelesaikan masalah tertentu. Beberapa karakteristik tersebut dapat digunakan sebagai indikator untuk mengukur kemampuan berpikir kreatif seseorang dalam menyelesaikan masalah tertentu, misalnya dalam bidang matematika. Kemampuankemampuan ini mempresentasikan proses menjadi sensitif pada pemahamanpemahaman seseorang, dan merupakan ciriciri utama berpikir kreatif yang telah berkembang. Selain itu kelancaran, keluwesan, keaslian dan elaborasi merupakan suatu mental manusia. 
Treffinger menunjukan saling hubungan dan ketergantungan antara keduanya dalam mendorong belajar kreatif. Sunata (Shoimin 2014: 217) mengungkapkan bahwa model treffinger adalah suatu strategi pembelajaran yang dikembangkan dari model belajar kreatif yang bersifat develop mental dan mengutamakan segi proses. Model treffinger untuk mendorong belajar kreatif menggambarkan susunan tiga tingkat yang mulai dengan unsur-unsur dasar dan menanjak ke fungsi-fungsi berpikir yang lebih majemuk. Siswa terlibat dalam membangun keterampilan pada dua tingkat pertama untuk kemudian menangani masalah kehidupan nyata pada tingkat ketiga.

Menurut Munandar (2012: 14) mengungkapkan bahwa model treffinger terdiri dari langkah-langkah berikut; basic tools, practice with process, dan working with real problems. Basic tools atau teknik kreativitas meliputi keterampilan berpikir divergen dan teknik-teknik kreatif. Pada bagian pengenalan, fungsi-fungsi divergen meliputi perkembangan dari kelancaran (fluency), kelenturan (flexibility), keaslian (originality), dan keterincian (elaboration) dalam berpikir. Pada bagian afektif, tahap 1 meliputi kesediaan untuk menjawab, keterbukaan terhadap pengalaman, kesediaan menerima kesamaan dan kedwiartian (ambiguity), kepekaan terhadap masalah dan tantangan, rasa ingin tahu, keberanian mengambil risiko, kesadaran dan kepercayaan kepada diri sendiri.

Practice with process, yaitu memberikan kesempatan kepada siswa untuk menerapkan keterampilan yang telah dipelajari pada tahap I dalam situasi praktik. Segi pengenalan pada tahap II ini meliputi penerapan, analisis, sintesis dan penilaian (evaluasi). Di samping itu termasuk juga transformasi dari beraneka produk dan isi, keterampilan metodelogis atau penelitian, pemikiran yang melibatkan analogi dan kiasan (metafor). Segi afektif pada tahap II mencakup keterbukaan terhadap perasaanperasaan dan konflik yang majemuk, mengarahkan perhatian pada masalah, penggunaan khayalan dan tamsil, meditasi dan kesantaian (relaxation), serta pengembangan keselamatan psikologis dalam berkreasi atau mencipta.

Working with real problems, yaitu menerapkan keterampilan yang dipelajari pada dua tahap pertama terhadap tantangan pada dunia nyata. Di sini siswa menggunakan kemampuannya dengan cara-cara yang bermakna bagi kehidupannya. Siswa tidak hanya belajar keterampilan, tetapi juga bagaimana menggunakan informasi ini dalam kehidupan mereka. Dalam ranah pengenalan, hal ini berarti keterlibatan dalam mengajukan pertanyaan-pertanyaan yang mandiri dan diarahkan sendiri. Belajar kreatif seseorang mengarah kepada identifikasi tantangantantangan atau masalah-masalah yang berarti, pengajuan pertanyaan-pertanyaan yang berkaitan dengan masalah-masalah tersebut, dan pengelolaan terhadap sumber-sumber yang mengarah pada perkembangan hasil atau produk.

\section{METODE}

Metode yang digunakan dalam penelitian ini adalah metode kuasi eksperimen, sedangkan desain penelitian yang digunakan adalah desain quasi experimental dengan bentuk the non-equivalent pretest-posttest control group design sebagai berikut.

$$
\underline{\mathrm{O}}-\underline{\mathrm{X}}_{-}-\underline{\mathrm{O}}
$$

(Lestari dan Yudhanegara, 2015: 138)

Pada desain ini di mana sebelum dilakukan penelitian kedua kelompok diberi pretest (O) untuk mengetahui keadaan awalnya. Selama penelitian berlangsung, kelompok pertama diberi perlakuan (X) dan kelompok yang lain diberi perlakuan seperti biasanya. Kelompok yang diberikan perlakuan dijadikan kelompok eksperimen dan kelompok yang diberi perlakuan seperti biasanya dijadikan kelompok 
Penerapan model pembelajaran treffinger untuk meningkatkan kemampuan berpikir

kreatif matematis siswa

kontrol. Selanjutnya diakhir penelitian, kedua kelas diberi posttest (O) untuk melihat hasilnya. Teknik penelitian yang digunakan dalam penelitian ini adalah purposive sampling yaitu teknik penentuan sampel berdasarkan dengan pertimbangan tertentu.

Sugiyono (2012: 61) mengemukakan bahwa populasi adalah wilayah generalisasi yang terdiri atas subyek yang mempunyai kualitas dan karakteristik tertentu yang ditetapkan oleh peneliti untuk dipelajari dan kemudian ditarik kesimpulannya. Maka populasi dalam penelitian ini adalah seluruh siswa-siswi kelas XI Madrasah Aliyah Mathla'ul Anwar Pusat Menes tahun ajaran 2017/2018. Sampel yang secara nyata akan diteliti harus refresentatif dalam arti mewakili populasi baik dalam karakteristik maupun jumlahnya. Hasil observasi diperoleh gambaran bahwa dalam penentuan kelas, pihak sekolah membagi siswa dengan jurusan masing-masing yang siswa pilih dan dibedakan berdasarkan program keahliannya. Adapun sampel dalam penelitian ini adalah kelas XI IPA 1 dan XI IPA 2 Madrasah Aliyah Mathla'ul Anwar Pusat Menes tahun ajaran 2017/2018.

Prosedur pengumpulan data dalam penelitian ini menggunakan metode observasi dan tes. Instrumen adalah suatu alat yang digunakan untuk mengumpulkan data dalam suatu penelitian (Lestari, 2015: 163). Instrumen yang digunakan dalam penelitian ini adalah dengan tes kemampuan berpikir kreatif matematis siswa. Bentuk tes yang digunakan adalah bentuk uraian. Sebelum digunakan dalam penelitian, instrumen terlebih dahulu diuji cobakan. Uji coba instrumen ini dilakukan untuk mengetahui gambaran terpenuhi tidaknya syarat-syarat instrumen sebagai pengumpul data yang baik. Statistik yang digunakan dalam menghitung data yang diperoleh dari hasil penelitian yaitu statistik parametrik, karena data yang diperoleh berdistribusi normal dan memiliki varian yang sama.

\section{HASIL DAN PEMBAHASAN}

Data yang diperoleh dalam penelitian ini adalah data nilai tes kemampuan berpikir kreatif matematis siswa berdasarkan hasil pretes dan postes pada kelas eksperimen dan kelas kontrol. Deskripsi data pretest kemampuan berpikir kritis matematis siswa kelas eksperimen dan kelas kontrol seperti pada Tabel 2 berikut.

Tabel 2. Deskripsi Data Pretest

\begin{tabular}{ccccccc}
\hline Kelas & N & $\begin{array}{c}\text { Nil } \\
\text { Mi } \\
\text { n }\end{array}$ & $\begin{array}{c}\text { Nil } \\
\text { ai } \\
\text { Ma } \\
\text { ks }\end{array}$ & $\begin{array}{c}\text { Mea } \\
\text { n }\end{array}$ & $\begin{array}{c}\text { Std. } \\
\text { Devi } \\
\text { asi }\end{array}$ & $\begin{array}{c}\text { Vari } \\
\text { ans }\end{array}$ \\
\hline $\begin{array}{c}\text { Eksperi } \\
\text { men }\end{array}$ & 26 & 10 & 50 & 28, & 8,16 & 66,72 \\
Kontrol & 26 & 10 & 45 & $\begin{array}{c}23 \\
25\end{array}$ & 8,98 & 80,70 \\
\hline
\end{tabular}

Berdasarkan Tabel 2 bahwa banyaknya siswa yang mengikuti pretest untuk siswa kelas eksperimen dan siswa kelas kontrol adalah 52 orang. Rata-rata nilai pretest siswa kelas eksperimen adalah 28,35 dan siswa kelas kontrol adalah 23,35. Nilai terendah untuk siswa kelas eksperimen dan siswa kontrol adalah 10. Nilai tertinggi siswa kelas eksperimen adalah 50 dan siswa kelas kontrol adalah 45. Dari hasil uji normalitas dan homogenitas data pretest siswa kelas eksperimen dan siswa kelas kontrol berdistribusi normal dan homogen. Selanjutnya dilakukan uji-t data pretest kemampuan berpikir kreatif matematis siswa kelas eksperimen dan siswa kelas kontrol seperti pada Tabel 3 berikut.

Tabel 3. Hasil Uji-t Data Pretest

\begin{tabular}{ccc}
\hline Jenis Uji & Statistik & Keputusan \\
\hline Uji-t & $t_{\text {hitung }}=0,84$ & Diterima \\
\hline
\end{tabular}

Berdasarkan Tabel 3 untuk uji satu pihak data pretes menunjukkan bahwa nilai $t_{\text {hitung }}=0,84$ dan $t_{\text {tabel }}=1,675$ dengan $\mathrm{dk}=n_{1}+n_{2}-2=26$ $+26-2=50$ dan $\alpha=0,05$. Karena nilai 0,84 $<$ 1,675 maka $H_{0}$ diterima. Dengan demikian dapat disimpulkan bahwa tidak terdapat perbedaan kemampuan awal berpikir kreatif 
matematis siswa kelas eksperimen dan siswa kelas kontrol. Deskripsi data postes kemampuan berpikir kritis matematis siswa kelas eksperimen dan siswa kelas kontrol seperti pada Tabel 4 berikut.

Tabel 4. Deskripsi Data Posttest

\begin{tabular}{ccccccc}
\hline Kelas & N & $\begin{array}{c}\text { Nilai } \\
\text { Min }\end{array}$ & $\begin{array}{c}\text { Nilai } \\
\text { Maks }\end{array}$ & Mean & $\begin{array}{c}\text { Std. } \\
\text { Devias } \\
\text { i }\end{array}$ & Varians \\
\hline $\begin{array}{c}\text { Eksperi } \\
\text { men }\end{array}$ & 26 & 60 & 95 & $\begin{array}{c}81, \\
65\end{array}$ & 9,14 & 83,53 \\
Kontrol & 26 & 45 & 80 & $\begin{array}{c}59, \\
50\end{array}$ & 10,18 & $\begin{array}{c}103,6 \\
3\end{array}$ \\
\hline
\end{tabular}

Berdasarkan Tabel 4 bahwa banyaknya siswa yang mengikuti posttest untuk siswa kelas eksperimen dan siswa kelas kontrol adalah 52 orang. Rata-rata nilai posttest siswa kelas eksperimen adalah 81,65 dan siswa kelas kontrol 59,50. Nilai terendah siswa kelas eksperimen adalah 60 dan siswa kelas kontrol adalah 45. Nilai tertinggi siswa kelas eksperimen adalah 95 dan siswa kelas kontrol adalah 80. Dari hasil uji normalitas dan homogenitas data posttest siswa kelas eksperimen dan siswa kelas kontrol berdistribusi normal dan homogen. Selanjutnya dilakukan uji-t data posttest kemampuan berpikir kreatif matematis siswa kelas eksperimen dan kelas kontrol seperti pada Tabel 5 berikut.

Tabel 5. Hasil Uji-t Data Posttest

\begin{tabular}{ccc}
\hline Jenis Uji & Statistik & Keputusan \\
\hline \multirow{2}{*}{ Uji-t } & $t_{\text {hitung }}=8,26$ & Ditolak \\
& $t_{\text {tabel }}=1,675$ & \\
\hline
\end{tabular}

Berdasarkan Tabel 5 untuk uji-t data posttest menunjukkan bahwa nilai $t_{\text {hitung }}=8,26$ dan $t_{\text {tabel }}=1,675$ dengan $\mathrm{dk}=n_{1}+n_{2}-2=26+26$ $-2=50$ dan $\alpha=0,05$. Karena nilai 8,26> 1,675 maka $H_{0}$ ditolak. Dengan demikian diperoleh kesimpulan bahwa terdapat perbedaan kemampuan berpikir kreatif matematis siswa kelas eksperimen dan siswa kelas kontrol. Deskripsi data gain kemampuan berpikir kritis matematis siswa kelas eksperimen dan siswa kelas kontrol seperti pada Tabel 6 berikut.

Tabel 6. Deskripsi Data Gain

\begin{tabular}{ccccccc}
\hline Kelas & N & $\begin{array}{c}\text { Nilai } \\
\text { Min }\end{array}$ & $\begin{array}{c}\text { Nilai } \\
\text { Maks }\end{array}$ & Mean & $\begin{array}{c}\text { Std. } \\
\text { Devia } \\
\text { si }\end{array}$ & $\begin{array}{c}\text { Varia } \\
\text { ns }\end{array}$ \\
\hline $\begin{array}{c}\text { Eksperi } \\
\text { men }\end{array}$ & 26 & 0,38 & $\begin{array}{c}0,9 \\
3\end{array}$ & 0,7 & 0,135 & $\begin{array}{c}0,01 \\
83 \\
\text { Kontrol }\end{array}$ \\
26 & 0,15 & $\begin{array}{c}0,7 \\
5\end{array}$ & $\begin{array}{c}0,4 \\
75\end{array}$ & 0,156 & $\begin{array}{c}0,02 \\
4\end{array}$ \\
\hline
\end{tabular}

Berdasarkan Tabel 6 bahwa rata-rata nilai gain siswa kelas eksperimen adalah 0,733 dan siswa kelas kontrol adalah 0,475. Nilai gain terendah siswa kelas eksperimen adalah o,38 dan siswa kelas kontrol adalah 0,15 . Nilai gain tertinggi siswa kelas eksperimen 0,93 dan siswa kelas kontrol adalah 0,75 . Rata-rata gain siswa kelas eksperimen lebih besar daripada rata-rata siswa kelas kontrol. Sebaran nilai gain siswa kelas eksperimen seperti pada Gambar 1 berikut.

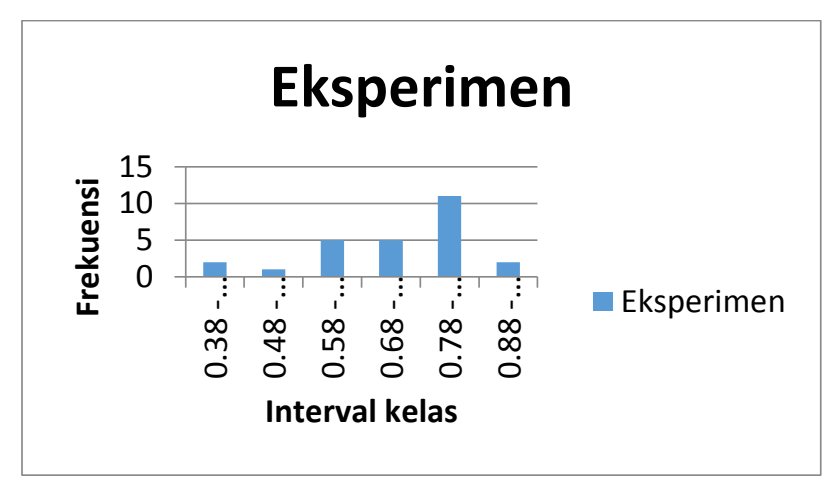

\section{Gambar 1. Nilai Gain Siswa Kelas Eksperimen}

Berdasarkan Gambar 1 bahwa sebaran data gain siswa kelas eksperimen dari 26 orang siswa, nilai yang paling banyak berada pada interval $0,78-0,87$ yaitu sebanyak 11 orang. Sebaran nilai gain siswa kelas kontrol seperti pada Gambar 2 berikut. 
Penerapan model pembelajaran treffinger untuk meningkatkan kemampuan berpikir kreatif matematis siswa

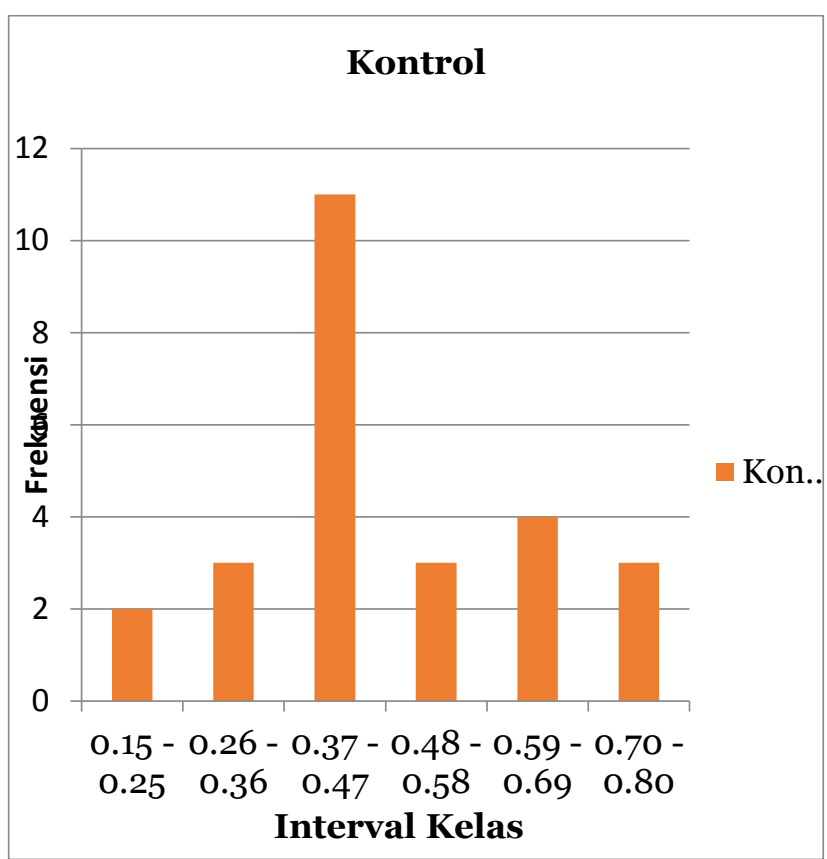

\section{Gambar 2. Nilai Gain Siswa Kelas Kontrol}

Berdasarkan Gambar 2 bahwa sebaran data gain siswa kelas kontrol dari 26 orang siswa, nilai yang paling banyak berada pada interval 0,37- 0,47 yaitu sebanyak 11 orang. Dari hasil uji normalitas dan homogenitas data gain siswa kelas eksperimen dan siswa kelas kontrol berdistribusi normal dan homogen. Selanjutnya dilakukan uji $-t$ data gain kemampuan berpikir kreatif matematis siswa kelas eksperimen dan siswa kelas kontrol seperti pada Tabel 7 berikut.

Tabel 7. Hasil Uji Satu Pihak Data Gain

\begin{tabular}{ccc}
\hline Jenis Uji & Statistik & Keputusan \\
\hline \multirow{2}{*}{ Uji-t } & $t_{\text {hitung }}=6,45$ & Ditolak \\
& $t_{\text {tabel }}=1,675$ & \\
\hline
\end{tabular}

Berdasarkan Tabel 7 untuk uji-t data gain menunjukkan bahwa nilai $t_{\text {hitung }}=6,45$ dan $t_{\text {tabel }}=1,675$ dengan $\mathrm{dk}=n_{1}+n_{2}-2=26+26$ $-2=50$ dan $\alpha=0,05$. Karena nilai $6,45>$ 1,675 maka $H_{0}$ ditolak. Dengan demikian diperoleh kesimpulan bahwa terdapat peningkatan kemampuan berpikir kreatif matematis siswa kelas XI Madrasah Aliyah
Mathla'ul Anwar Pusat Menes melalui model pembelajaran treffinger.

Penelitian ini diawali dengan pemberian pretes berpikir kreatif matematis siswa pada pertemuan pertama baik di kelas eksperimen maupun di kelas kontrol. Setelah itu dilakukan pembelajaran menggunakan model pembelajaran treffinger. Diakhir pertemuan, siswa diberikan postes berpikir kreatif matematis. Hal ini dilakukan untuk mengetahui perkembangan kemampuan berpikir kreatif matematis siswa setelah proses pembelajaran dengan model treffinger.

Berdasarkan hasil nilai pretes diperoleh nilai rata-rata kemampuan berpikir kreatif matematis siswa kelas eksperimen sebesar 28,35 dan rata-rata siswa kelas kontrol 23,35. Hal ini menujukkan bahwa sebaran data kemampuan berpikir kreatif matematis siswa merata. Nilai terendah untuk siswa kelas eksperimen dan siswa kelas kontrol 10, nilai tertinggi siswa kelas eksperimen 50 dan siswa kelas kontrol 45. Untuk memperjelas kemampuan awal tersebut, dilakukan uji-t pihak dengan hasil $t_{\text {hitung }}=0,84$ lebih kecil dari pada $t_{\text {tabel }}=1,675$, sehingga diperoleh hasil bahwa tidak terdapat perbedaan rata-rata kemampuan awal berpikir kreatif matematis siswa kelas eksperimen dan siswa kelas kontrol. Setelah diketahui bahwa kedua kelas mempunyai kemampuan awal yang sama maka dilakukan pembelajaran pada kedua kelas dengan pokok bahasan suku banyak. Pembelajaran di kelas eksperimen menggunakan model pembelajaran treffinger dan di kelas kontrol menggunakan pembelajaran konvensional.

Setelah dilakukan pembelajaran, rata-rata postes kemampuan berpikir kreatif matematis siswa kelas eksperimen adalah sebesar 81,65 dan siswa kelas kontrol sebesar 59,50. Hal ini menunjukkan bahwa sebaran data kemampuan berpikir kreatif siswa merata. Nilai terendah siswa kelas eksperimen 60 dan siswa kelas kontrol 45, nilai tertinggi siswa kelas eksperimen 95 dan siswa kelas kontrol 80. Berdasarkan penghitungan, karena nilai $t_{\text {hitung }}$ 
$=8,26$ lebih dari $t_{\text {tabel }}=1,675$ untuk uji-t, sehingga $H_{0}$ ditolak dan $H_{1}$ diterima, maka terdapat perbedaan kemampuan berpikir kreatif matematis siswa antara siswa kelas eksperimen dan kelas kontrol.

Setelah dilakukan analisis data gain, rata-rata peningkatan kemampuan berpikir kreatif matematis siswa kelas eksperimen adalah o,733 yang termasuk ke dalam kriteria tinggi dan siswa kelas kontrol sebesar 0,475 yang termasuk ke dalam kriteria rendah. Nilai standar deviasi siswa kelas eksperimen 0,135 dan siswa kelas kontrol 0,156. Hal ini menunjukkan bahwa sebaran data kemampuan berpikir kreatif siswa merata. Nilai terendah untuk siswa kelas eksperimen o,38 dan kelas kontrol 0,15. Nilai tertinggi siswa kelas eksperimen 0,93 dan siswa kelas kontrol 0,75.

Berdasarkan penghitungan, karena nilai $t_{\text {hitung }}$ $=6,45$ lebih dari $t_{\text {tabel }}=1,675$ untuk uji-t, sehingga $H_{0}$ ditolak dan $H_{1}$ diterima, maka dapat disimpulkan peningkatan kemampuan berpikir kreatif matematis siswa kelas eksperimen lebih baik daripada siswa kelas kontrol.

\section{KESIMPULAN}

Bedasarkan hasil pengolahan data dan pengujian hipotesis penelitian di Madrasah Aliyah Mathla'ul Anwar Pusat Menes, maka diperoleh kesimpulan hasil penelitian tentang penerapan model pembelajaran treffinger terhadap peningkatan kemampuan berpikir kreatif matematika siswa kelas XI Madrasah Aliyah Mathla'ul Anwar Pusat Menes tahun pelajaran 2017/2018 menunjukan bahwa kemampuan berpikir kreatif matematis siswa yang memperoleh model pembelajaran treffinger lebih baik dari pada siswa yang memperoleh pembelajaran konvensional. Hasil penelitian ini diharapkan dapat meningkatkan kemampuan berpikir kreatif siswa pada pembelajaran matematika. Pembelajaran triffenger dapat dijadikan oleh guru sebagai salah satu variasi dalam pemilihan strategi mengajar, terutama berdasarkan hasil analisa dan pengamatan peneliti dari kedua model pembelajaran treffinger lebih baik dibandingkan dengan konvensional, karena pada model pembelajaran ini kemampuan berpikir siswa meningkat lebih baik. Satu sama lain bertanggung jawab atas keberhasilan kelompoknya, sehingga ada kemauan siswa untuk saling memberikan arahan, menghilangkan rasa takut siswa untuk bertanya dan menayakan. Hal ini berdampak pada belajar yang mereka peroleh mengalami peningkatan.

\section{Referensi}

Departemen Pendidikan Nasional. (2003). Undang-Undang Republik Indonesia Nomor 20 Tahun 2003 Tentang Sistem Pendidikan Nasional Pasal 3.

Lestari, K.L., \& Yudhanegara, M.R. (2015). Penelitian Pendidikan Matematika: Karawang: Reflika Aditama.

Meika, I., \& Sujana, A. (2015). Pengaruh Pembelajaran Konflik Kognitif untuk Meningkatkan Kemampuan Berpikir Kreatif Matematis Siswa SMA. MENDIDIK: Jurnal Kajian Pendidikan dan Pengajaran. 1 (1), 9-17.

Moma, L. (2015). Pengembangan Instrumen Kemampuan Berpikir Kreatif Matematis Untuk Siswa SMP. Delta-pi: Jurnal Matematika dan Pendidikan Matematika. 4 (1), 27-41.

Munandar, U. (2012). Pengembangan Kreativitas Anak Berbakat. Jakarta: Rineka Cipta.

Kariadinata, R., Yaniawati, R. P., Sugilar, H., \& Riyandani, D. (2019). Learning motivation and mathematical understanding of students of islamic junior high school through active knowledge sharing strategy. Infinity Journal, 8(1), 31-42.

Shoimin, A. (2014). 68 Model Pembelajaran Inovatif dalam Kurikulum 2013. Yogyakarta: Ar-Ruzz Media.

Sobarningsih, N., Sugilar, H., Nurdiansyah, R., \& Turmudzi, I. (2019, March). Building Systematic Think Ability. In Social and 
Penerapan model pembelajaran treffinger untuk meningkatkan kemampuan berpikir kreatif matematis siswa

Humaniora Research Symposium (SoRes 2018). Atlantis Press.

Sobarningsih, N., Sugilar, H., \& Nurdiansyah, R. (2019). Analisis Implementasi Standar Proses Pembelajaran Guru Matematika. Prima: Jurnal Pendidikan Matematika, 3(1), 67-84.

Sugiyono. (2012). Statistika Untuk Penelitian. Bandung: CV Alfabeta.

Yusuf, S.L.N. (2016). Psikologi Perkembangan Anak \& Remaja. Bandung: Remaja Posdakarya. 